\title{
Annual metabolic carbon balance of the seagrass Posidonia oceanica: the importance of carbohydrate reserves
}

\author{
Teresa Alcoverro*, Marta Manzanera, Javier Romero \\ Departament d'Ecologia, Universitat de Barcelona, Avgda. Diagonal 645, 08028 Barcelona, Spain
}

\begin{abstract}
We present the seasonal carbon (C) balance of the Mediterranean seagrass Posidonia oceanica (L.) Delile calculated from seasonal rates of C gain (photosynthesis), C loss (respiration) and growth. We compare our balance with the evolution of seasonal C reserves in order to determine the parameters (shoot:root biomass, reserve allocation, photosynthetic parameters, etc.) that influence the seasonal cycle of the plant. Additionally, we examine whether the annual C balance can be used as a valid tool for testing the vulnerability of seagrasses to light reduction. The seasonal whole-plant C balance showed alternate negative (from September to June) and positive (July and August) values. This trend was the result of the interplay among several seasonal factors such as irradiance, water turbidity, photosynthetic parameters, respiratory rates, shoot growth, within-shoot age distribution, and principally, the low photosynthetic:non-photosynthetic biomass ratio. The lack of significant correlation between seasonal growth and metabolic balance (C gain - $\mathrm{C}$ demand) did not permit the prediction of plant growth. Conversely, the seasonal pattern of carbon storage was consistent with the periods of positive and negative $\mathrm{C}$ balance. Consequently, reserve mobilization allows overwintering and re-growth under conditions of negative $\mathrm{C}$ balance. Using different calculations the annual C balance was found to be negative during 1993; this is in accordance with the carbohydrate interannual depletion and the shoot density decline. Since Posidonia oceanica is regressing in the Mediterranean, our carbon budget may notably contribute to future carbon models that can be essential tools for defining the minimum light requirements for survival. More insight into the functioning of some of the parameters that definitively influence this carbon budget (e.g.: the rhizome/root oxygen consumption and the $\mathrm{O}_{2}$ to $\mathrm{C}$ conversion) is needed to fully understand the vulnerability of seagrasses to light reduction.
\end{abstract}

KEY WORDS: Mediterranean sea $\cdot$ Photosynthesis $\cdot$ Respiration $\cdot$ Irradiance $\cdot$ Starch $\cdot$ Sucrose

\section{INTRODUCTION}

In plant ecophysiology, in spite of increasing knowledge of the individual components of the C economy, integration at the whole-plant level is still arduous. In terrestrial plants $\mathrm{C}$ balance models are being used increasingly, mainly with annual species and, to a

\footnotetext{
*Present address: Centre d'Estudis Avançats de Blanes, CSIC, Camí de Santa Bàrbara s/n, 17300 Blanes, Girona, Spain. E-mail: teresa@ceab.csic.es
}

lesser extent, with deciduous fruit crops (Heim et al. 1979, Gutiérrez et al. 1985, Seem et al. 1986, AbdelRazik 1989) or other perennial species (Makela \& Hari 1986, Janecek et al. 1989). These C models examine the balance between $\mathrm{C}$ supply and demand, and, within demand, the partitioning among maintenance, growth and reserve regeneration.

Knowledge of the temporal pattern of allocation of carbon resources to growth, maintenance or regeneration of carbon reserves is critical for an understanding of the whole-plant responses to environmental stress and to production dynamics. In particular, reserves 
may be important for wintertime survival of either high to mid-latitude macrophytes or plants under prolonged stress (Chapman \& Craigie 1978, Dunton 1990, Buwalda 1991, Alcoverro et al. 1999).

Seagrasses are known to have some of the highest rates of primary production for marine systems in coastal areas and recently have been considered as major contributors to the net carbon production stored and subsequently buried in marine sediments (Duarte \& Cebrián 1996).

Despite the importance of seagrasses in the global carbon cycle, few attempts have been made to integrate all the processes into carbon budgets, and only few studies have considered seasonality and extreme values of light availability, dependent on either sun angle, weather conditions or water transparency throughout the year (Pérez \& Romero 1992, Dunton 1994, Zimmerman et al. 1994, Lee \& Dunton 1997, Herzka \& Dunton 1998).

Posidonia oceanica, the dominant seagrass in Mediterranean coastal waters, shows remarkable features that include: (1) a strong seasonality of leaf growth, with rates usually highest in late spring and lowest in late summer (Alcoverro et al. 1995), (2) a high capacity for seasonal carbohydrate storage (Pirc 1989), which seems to influence plant survival (Genot et al. 1994), and (3) high belowground biomass (belowground to leaf biomass ratio between 3 and 15; Ott 1980, Pirc 1983, Romero 1985), which can generate a very high respiratory demand (e.g. Fourqurean \& Zieman 1991 for Thalassia testudinum).

The answer to the question how these features affect the carbon budget of the plant would improve our knowledge about the basic processes influencing seagrass growth and survival and would enable the quantification of the relative costs (respiratory demand) and benefits (carbon storage) of a large belowground biomass. Moreover, as in other seagrasses, Posidonia oceanica is undergoing significant decline (at least in the Northwestern Mediterranean; Sánchez-Lizaso et al. 1990, Zavodnik \& Jaklin 1990, Marbà et al. 1996), which may be due in part to increasing turbidity of coastal waters or to increasing epiphyte loading, both effects being results of increased eutrophication. The plant's sensitivity to the reduction in light availability is an immediate consequence of how and when the carbon budget is achieved, and thus the modeling of such a budget becomes a major tool in assessing and, eventually, preventing seagrass decline.

Here, we present the seasonal $\mathrm{C}$ balance of the Mediterranean seagrass Posidonia oceanica obtained from seasonal rates of $\mathrm{C}$ gain (photosynthesis), C loss (respiration) and growth. We compare our balance with the seasonal $C$ reserve evolution in order to understand the seasonal patterns of the plant. Addi- tionally we examine whether the annual $\mathrm{C}$ balance can be used as a valid tool for preventing seagrass decline.

\section{METHODS}

Experimental design. The study was conducted in a Posidonia oceanica meadow off the Medes Islands (NE coast of Spain: $42^{\circ} 2^{\prime} \mathrm{N}, 3^{\circ} 13^{\prime} \mathrm{E}$ ) in a site close to the upslope limit of the meadow $(-5.0 \mathrm{~m})$. Shoot density in this meadow was about 600 shoots $\mathrm{m}^{-2}$ and the majority of the rhizomes were on a vertical-growing axis (ca $75 \%$ ).

Plant material for laboratory experiments was collected by SCUBA divers at noon and transported in the dark in aerated seawater to the laboratory within $3 \mathrm{~h}$ of collection.

Approximately every 2 mo (a total of 8 sampling events, from November 1992 to December 1993) 10 shoots, chosen at random over an area of ca $100 \mathrm{~m}^{2}$, were marked ( 1 mo before collection) to estimate leaf growth, using the Zieman method modified by Romero (1989) and biomass. Ten additional shoots were collected at each sampling for the metabolic and carbohydrate reserve measurements.

Growth rates, biomass allocation and metabolic rates. Harvested shoots were rinsed and epiphytes were removed with a razor blade. Leaf elongation, length and sheath length of the marked shoots were measured. Shoots were then dried $\left(70^{\circ} \mathrm{C}\right.$ to constant weight) and each part weighed separately. Sheath growth was estimated as described in Romero (1985).

The 10 additional shoots were divided into photosynthetic parts (leaf blades) and non-photosynthetic parts (leaf sheaths, rhizomes and roots). The photosynthetic parts were sorted into segments corresponding to the following age classes (in days): 0 to 25 (A1), 25 to 50 (A2), 50 to 100 (A3) and 100 to 150 (A4). Photosynthesis vs irradiance curves $(P-I)$ were obtained for each age class. A description of the method and the results of these incubations have been reported elsewhere (Alcoverro et al. 1998), and the resulting photosynthetic parameters are summarized in Table 1.

The respiratory demand of belowground parts was determined experimentally, except for the remnant dead sheaths (scales) attached to the rhizomes (Pergent et al. 1983, Mateo 1995). In effect, even when the remnant dead sheaths represented a large biomass, their respiratory demand was considered to be negligible, as demonstrated by Manzanera et al. (1998).

Hence, respiration rates of rhizomes (upper $5 \mathrm{~cm}$ ), roots (only those growing from the upper $10 \mathrm{~cm}$ of rhizome) and live sheaths were determined for each sampling in 3 replicate samples in the dark using temperature-controlled incubators (the same water temperatures recorded at the moment of collection, which 
Table 1. List of physiological constants used in the leaf carbon balance, $P_{\max }$ : production at saturating irradiance; $I_{\mathrm{c}}$ : compensation irradiance; $I_{k}$ : saturating irradiance; Resp: respiration, and carbon concentration in leaves (as a percentage of dry weight; source: from Alcoverro et al. 1998, 2000). The photosynthetic parts were sorted into segments corresponding to the following age classes (in days): A1, leaf 0 to $25 \mathrm{~d}_{\text {; }} \mathrm{A} 2$, leaf 25 to $50 \mathrm{~d} ; \mathrm{A} 3$, leaf 50 to $100 \mathrm{~d}$; A4, leaf 100 to $150 \mathrm{~d}$

\begin{tabular}{|c|c|c|c|c|c|}
\hline Constant & Month & A1 & A2 & A3 & A4 \\
\hline $\begin{array}{l}P_{\max } \\
\left(\mathrm{mg} \mathrm{O}_{2} \mathrm{~g}^{-1} \mathrm{DW} \mathrm{h}^{-1}\right)\end{array}$ & $\begin{array}{l}\text { Dec } \\
\text { Feb } \\
\text { May } \\
\text { Jul } \\
\text { Sep }\end{array}$ & $\begin{array}{c}7.3 \\
11.8 \\
10.4 \\
11.3 \\
10.9\end{array}$ & $\begin{array}{c}8.7 \\
11.4 \\
13.6 \\
10.5 \\
11.1\end{array}$ & $\begin{array}{l}7.8 \\
9.8 \\
4.2 \\
6.2 \\
7.7\end{array}$ & $\begin{array}{l}7.2 \\
2.6 \\
1.9 \\
2.9 \\
6.2\end{array}$ \\
\hline $\begin{array}{l}I_{k} \\
\left(\mu \mathrm{mol} \text { quanta } \mathrm{m}^{-2} \mathrm{~s}^{-1}\right)\end{array}$ & $\begin{array}{l}\text { Dec } \\
\text { Feb } \\
\text { May } \\
\text { Jul } \\
\text { Sep }\end{array}$ & $\begin{array}{c}8.2 \\
433 \\
419 \\
256 \\
225\end{array}$ & $\begin{array}{c}16 \\
362 \\
542 \\
398 \\
362\end{array}$ & $\begin{array}{c}92 \\
186 \\
290 \\
387 \\
488\end{array}$ & $\begin{array}{c}98 \\
8.9 \\
197 \\
234 \\
470\end{array}$ \\
\hline $\begin{array}{l}I_{\mathrm{c}} \\
\left(\mu \mathrm{mol} \text { quanta } \mathrm{m}^{-2} \mathrm{~s}^{-1}\right)\end{array}$ & $\begin{array}{l}\text { Dec } \\
\text { Feb } \\
\text { May } \\
\text { Jul } \\
\text { Sep }\end{array}$ & $\begin{array}{c}1.5 \\
56.1 \\
76.7 \\
27.3 \\
33.3\end{array}$ & $\begin{array}{c}2.5 \\
24.8 \\
38.4 \\
38 \\
31.9\end{array}$ & $\begin{array}{c}19 \\
16 \\
66.6 \\
70.6 \\
49.2\end{array}$ & $\begin{array}{c}16.8 \\
3.3 \\
76.9 \\
81.7 \\
49.2\end{array}$ \\
\hline $\begin{array}{l}\text { Resp } \\
\left(\mathrm{mg} \mathrm{O}_{2} \mathrm{~g}^{-1} \mathrm{DW} \mathrm{h}^{-1}\right)\end{array}$ & $\begin{array}{l}\text { Dec } \\
\text { Feb } \\
\text { May } \\
\text { Jul } \\
\text { Sep }\end{array}$ & $\begin{array}{c}1.43 \\
1.34 \\
1.39 \\
0.7 \\
1.3\end{array}$ & $\begin{array}{c}1.27 \\
1.1 \\
0.84 \\
0.72 \\
0.62\end{array}$ & $\begin{array}{l}1.32 \\
1.26 \\
1.01 \\
1.42 \\
0.85\end{array}$ & $\begin{array}{l}1.52 \\
1.63 \\
1.05 \\
1.52 \\
1.16\end{array}$ \\
\hline \% leaf carbon & Annual & 36.3 & 35.3 & 34.6 & 32.8 \\
\hline
\end{tabular}

ranged from 13 to $24^{\circ} \mathrm{C}$ ) with the same methodology reported in Alcoverro et al. (1998). To assess the possible bias introduced by incubating only the upper, most active plant tissue ( 0 to $5 \mathrm{~cm}$ for rhizomes, 0 to $10 \mathrm{~cm}$ for roots) 8 additional shoots with long rhizomes were collected in January. Roots were divided into 2 classes: apical (growing from the rhizome between 0 and $10 \mathrm{~cm}$ ) and basal (between 10 and $20 \mathrm{~cm}$ ), and rhizomes were divided into 4 classes whenever possible ( 0 to $5 \mathrm{~cm}, 5$ to $10 \mathrm{~cm}, 10$ to $15 \mathrm{~cm}$ and $>20 \mathrm{~cm}$ ) and incubated as indicated above. These 4 classes were converted to age classes by dating the rhizome segments (see Pergent et al. 1989). The biomass-age distribution was obtained by weighing the rhizomes corresponding to each age class and calculating their relative percentage with respect to the total rhizome biomass. After each incubation, the plant material was dried at $70^{\circ} \mathrm{C}$ to constant weight and subsequently weighed. All results are expressed in $\mathrm{mg} \mathrm{O}_{2} \mathrm{~g} \mathrm{DW}^{-1} \mathrm{~h}^{-1}$.

Biomass of belowground organs was estimated with 4 corers of $15 \mathrm{~cm}$ section (see 'Methodology' in Mateo \& Romero 1997) collected in January; seasonal changes in Posidonia oceanica rhizome and root biomass are not relevant (Cebrián et al. 1997), since annual growth is only a small fraction of their total biomass. Growth of belowground organs (rhizomes and roots) are those given by Mateo \& Romero (1997) from the same station (Table 2).

Total carbohydrate reserves. Subsamples of photosynthetic and non-photosynthetic dried (within $6 \mathrm{~h}$ after collection) tissues were used for measuring total nonstructural carbohydrates (\%TNC). Soluble carbohydrates and starch (TNC) were extracted from the ground dry tissues in hot $\left(80^{\circ} \mathrm{C}\right)$ ethanol and then analysed using the methods described in Alcoverro et al. (1999).

Statistical analyses. Statistical significance of time (seasonality) or tissue effect was determined by 1-way ANOVA for each variable measured (Sokal \& Rohlf 1981).

Whole-plant $\mathbf{C}$ balance calculations. Hourly data of surface irradiance $\left(\mathrm{W} \mathrm{m}^{-2}\right)$ were obtained from a station close (ca $20 \mathrm{~km}$ ) to the study site, and then transformed to $\mu \mathrm{mol}$ quanta $\mathrm{m}^{-2} \mathrm{~s}^{-1}\left(1 \mu \mathrm{mol}\right.$ quanta $\mathrm{m}^{-2} \mathrm{~s}^{-1}=0.217 \mathrm{~W}$ $\mathrm{m}^{-2}$, Valiela 1995). These data were transformed to subsurface quantum irradiance following Kirk (1983) to account for the reflection at the sea surface. The subsurface quantum irradiance was then transformed using the Beer-Lambert expression $\left(I_{z}=I_{0} \times \mathrm{e}^{-K_{d} z}\right.$, where $I_{z}$ and $I_{0}$ are the irradiances at depth $z$ and the surface, respectively, and $K_{d}$ is the coefficient of light attentuation, $\mathrm{m}^{-1}$ ) to estimate the absorption (including scattering) in the water column. The attenuation coefficient was estimated from weekly measurements (Secchi disk) of water transparency and then applying the expression of Weinberg \& Cortel-Breeman (1978) as below:

$$
K_{d}=\frac{2.6}{\left(D_{\mathrm{s}}+2.5\right)}-0.048
$$

where is $D_{\mathrm{s}}$ the Secchi disk depth (m).

Table 2. Values used in the belowground carbon balance, and their sources

\begin{tabular}{|c|c|c|}
\hline Variable & Value & Source \\
\hline $\begin{array}{l}\text { Rhizome biomass } \\
\left(\mathrm{g} \mathrm{DW} \mathrm{shoot}^{-1}\right)\end{array}$ & 0.79 & This study \\
\hline $\begin{array}{l}\text { Root biomass } \\
\left(\text { g DW shoot }^{-1}\right)\end{array}$ & 0.47 & This study \\
\hline $\begin{array}{l}\text { Leaf sheaths biomass } \\
\left(\mathrm{g} \text { DW shoot }{ }^{-1}\right)\end{array}$ & 0.083 & This study \\
\hline $\begin{array}{l}\text { Rhizome growth } \\
\left(\mathrm{mg} \mathrm{DW} \mathrm{shoot}^{-1} \mathrm{~d}^{-1}\right)\end{array}$ & 0.24 & Mateo \& Romero 1997 \\
\hline $\begin{array}{l}\text { Root growth } \\
\left(\mathrm{mg} \mathrm{DW} \mathrm{shoot}^{-1} \mathrm{~d}^{-1}\right)\end{array}$ & 0.09 & Mateo \& Romero 1997 \\
\hline \% C (rhizome) & 38.4 & Alcoverro et al. (2000) \\
\hline$\% \mathrm{C}$ (root) & 41.5 & Alcoverro et al. (2000) \\
\hline \% C (leaf sheaths) & 30.6 & Alcoverro et al. (2000) \\
\hline
\end{tabular}


Net $\mathrm{C}$ gain (positive or negative, $\mathrm{mg} \mathrm{O}_{2} \mathrm{~g} \mathrm{DW}^{-1} \mathrm{~h}^{-1}$ ) in each leaf age class (A1, A2, A3, A4) at time $i$, was calculated for the light hours from the following equation (Edwards \& Walker 1983):

$$
\text { Leaf C } \text { gain }_{i j}=\frac{\left[P_{\max _{i j}} \times\left(I-I_{\mathrm{C}_{i j}}\right)\right]}{I_{k_{i j}}+I-I_{\mathrm{C}_{i j}}}
$$

where $j=1$ to 4 corresponds to the leaf age, $I$ is the hourly incoming quantum irradiance at the canopy level, $I_{k_{i j}}, P_{\max _{i j}}$ and $I_{\mathrm{c}_{i j}}$ are the photosynthetic parameters at time $i$ for the age class $j$ reported in Table 1. For the dark hours, $\mathrm{C}$ gain was assumed to be equal to respiration.

C gain (or loss) of whole shoot was determined as follows:

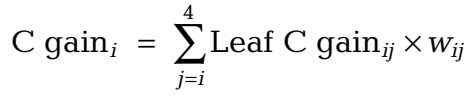

where $\mathrm{C}$ gain $_{i}$ is the carbon gain (in $\mathrm{mg} \mathrm{C} \operatorname{shoot}^{-1} \mathrm{~h}^{-1}$ ) at time $i$, and $w_{i j}$ is the weight of the leaves $\left(\mathrm{g} \mathrm{shoot}^{-1}\right)$ of age $j$ at time $i$.

Daily C gain (mg C shoot ${ }^{-1} \mathrm{~d}^{-1}$ ) was obtained by integrating these data on a $24 \mathrm{~h}$ basis.

Seagrass leaf epiphytes have also been proposed to significantly reduce light and consequently photosynthesis (e.g. Sand-Jensen 1977, Hootsman \& Vermaat 1985, Silberstein et al. 1986). We examined this contention using the $P$ - $I$ curves presented here, the epiphyte distribution following leaf age (authors' unpubl. data) and data of epiphyte light absorption reported in Alcoverro et al. (1997a). According to these data, significant light reduction will only take place in tissues older than $100 \mathrm{~d}$ (A4 age class), and will reduce, on average, $32 \%$ of the incident light between May and August. This reduction has been taken into account when estimating the $\mathrm{C}$ gain.

$\mathrm{C}$ demand of root, rhizome and sheaths was calculated from the measured rates of respiration. Aggregate metabolic rates of belowground tissue (rhizomes and roots) for each sampling event were calculated by scaling the measured rates of respiration of the sheath, the first 0 to $5 \mathrm{~cm}$ of rhizome and uppermost roots (growing from the rhizome between 0 and $10 \mathrm{~cm}$ ) to the total biomass in each shoot (Table 2). Age rhizome biomass distribution was incorporated to account for the differences in metabolic oxygen uptake between the upper parts and the rest. Daily $\mathrm{C}$ demand (mg C shoot $^{-1} \mathrm{~d}^{-1}$ ) was obtained by integrating these data on a $24 \mathrm{~h}$ basis.

Daily growth rate $\left(\mathrm{mg} \mathrm{C}\right.$ shoot $\left.{ }^{-1} \mathrm{~d}^{-1}\right)$ was obtained by adding the leaf growth to the growth of non-photosynthetic parts (roots, rhizomes and sheaths) and converted to $\mathrm{C}$ units using data of carbon concentration
(Tables $1 \& 2$ ). When, for a given month, growth data were not available, an estimate was made by averaging growth between the previous and the following months.

Daily plant $\mathrm{C}$ balance at time $i$ (in $\mathrm{mg} C \operatorname{shoot}^{-1} \mathrm{~d}^{-1}$ ) was obtained as:

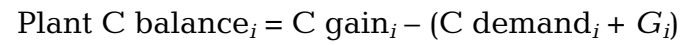

where $G$ is daily growth rate. For the sake of clarity, data are presented as monthly averages.

Integration of carbon gains has been observed to be very sensitive to some parameters such as (1) the reduction of respiration of roots and rhizomes, which takes place when the oxygen supply from leaves drops (i.e. night conditions), assumed by some authors to be $65 \%$ of the rate in the light (aerobic) period (Smith et al. 1984), or (2) the photosynthetic conversion ratio from $\mathrm{O}_{2}$ to $\mathrm{C}$ units that has been considered to be either $1 \mathrm{~mol}$ of $\mathrm{O}_{2}: 1 \mathrm{~mol} \mathrm{CO}$ (Herzka \& Dunton 1998) or $1.2 \mathrm{~mol}$ of $\mathrm{O}_{2}: 1 \mathrm{~mol} \mathrm{CO}_{2}$ (Zimmerman et al. 1996). To test our carbon budget sensitivity to these parameters, values were calculated using the extreme values of the preceding parameters.

The carbon balance was computed for 1993, during which time most of the experimental values were obtained. Additionally, and for the sake of comparison, we evaluated the carbon balance for 1994, in which light and water transparency were also available, and assuming the same biomass, growth, respiration and photosynthetic parameters calculated in 1993.

\section{RESULTS}

\section{Environmental variables}

Daily integrated measurements of photosynthetic active radiation in air collected between December 1992 and December 1993 showed maximum values from spring to the late summer and minimum values in the winter period (Fig. 1a). The attenuation coefficient showed maximum values during winter and spring, and the lowest during summer (Fig. 1b). Irradiance at $-5 \mathrm{~m}$ (canopy level) presented the highest values in summer and the lowest in winter, with some particularly low values during spring (Fig. 1a). Variations in the daily integrated measurements of photosynthetic active radiation at the canopy level are better explained by the variability in air irradiance $\left(\mathrm{R}^{2}=\right.$ $0.82, \mathrm{p}<0.001)$, than by variability in water transparency $\left(R^{2}=0.07\right.$, not significant). In fact, the irradiance at the canopy level shows a clear autocorrelation $(\mathrm{R}>0.5$ until lag $=20 \mathrm{~d}, \mathrm{p}<0.001)$ that highlights the clear serial dependency of this variable. 


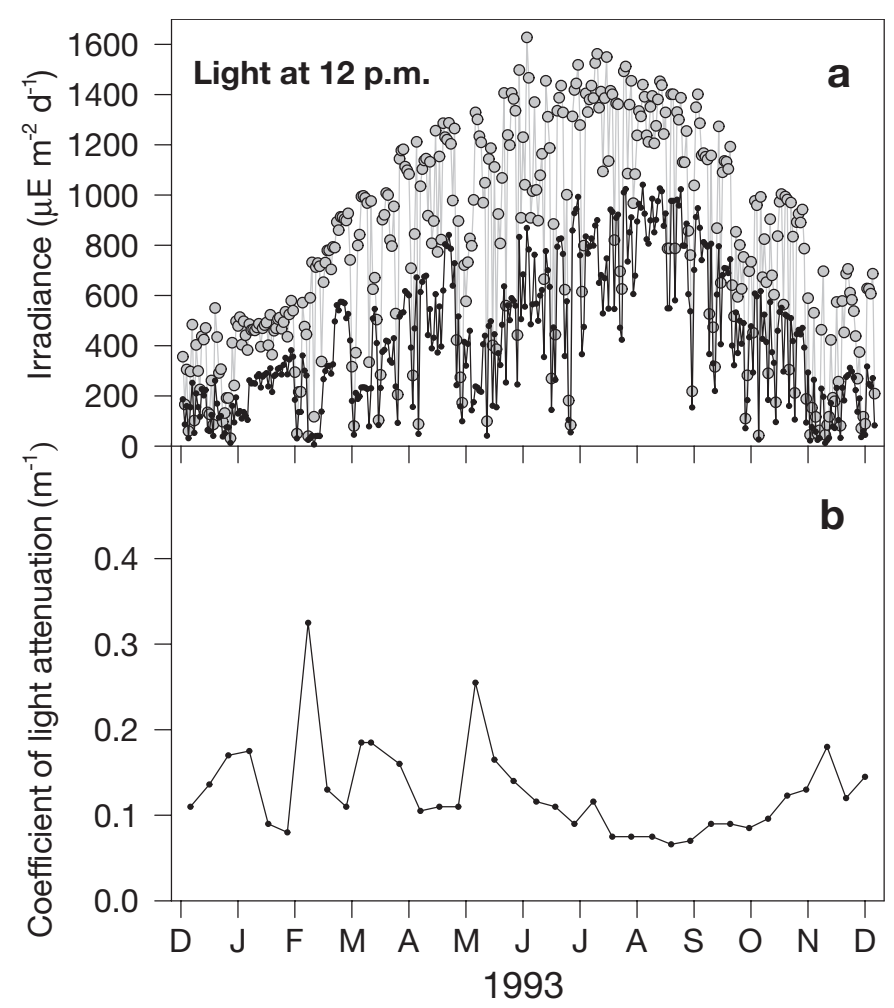

Fig. 1. Curve showing (a) irradiance seasonal pattern at the surface $(+0 \mathrm{~m}, 0)$ and at $-5 \mathrm{~m}$ depth $(\bullet)$ and $(\mathrm{b})$ the attenuation coefficient $\left(\mathrm{m}^{-1}\right)$ obtained with the Secchi disc every week

\section{Growth rates, biomass allocation and metabolic rates}

Shoot size and growth (including leaves and sheaths) showed high seasonal variability. Shoots were largest in late summer and decreased in size during fall, while the shoot growth was at a maximum in June and declined at the end of summer (Fig. 2). Biomass allocation was highest in the rhizome compared to the roots and sheaths (Table 2). Among the non-photosynthetic organs, leaf sheaths showed the highest respiration values (Fig. 3). Nevertheless, none of those organs had values higher than the leaves (Table 1). Leaf sheath and root respiration exhibited a clear seasonality (Fig. 3, Table 3), with the highest values in spring, coinciding with maximum leaf elongation rates (Fig. 2). Seasonal changes in rhizome respiration, although with a relative maximum in July, showed only marginal signification (Table 3, Fig. 3a). Rhizome segments clearly showed a respiration decrease with tissue age (Fig. 3b, ANOVA, $p<0.05$ ). The respiration rate of the youngest rhizome segment $(0$ to $5 \mathrm{~cm}$ ) was statistically different from the rest of the segments (Tukey's HSD test, $\mathrm{p}<0.05$ ). No significant differences were observed among root classes (ANOVA, p > 0.05).

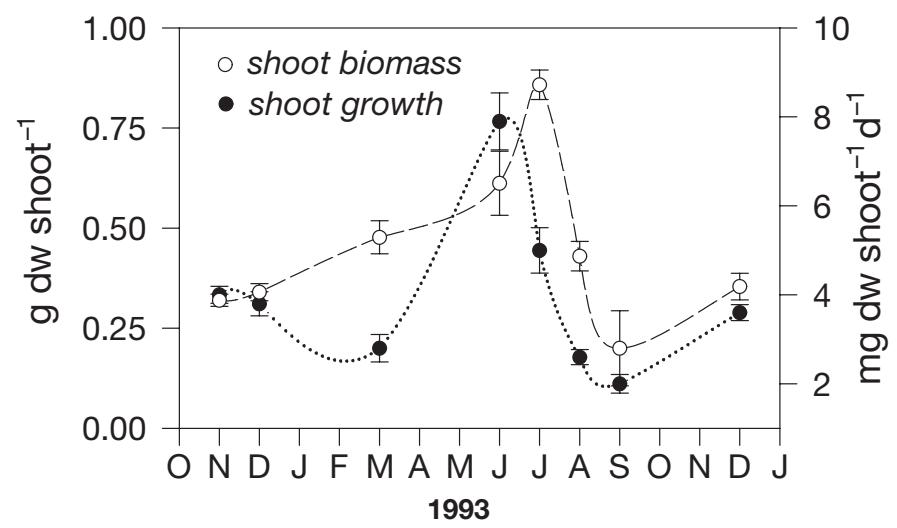

Fig. 2. Seasonal changes in biomass per shoot and growth per shoot (both leaves and leaf sheaths). Error bars represent the standard error $(n=10)$

\section{Carbohydrate reserves}

Seasonal changes in total (sucrose and starch) nonstructural carbohydrate content (TNC) were consistent across plant organs and leaf age classes (Fig. 4a-d, Table 3), with the highest values from July to September and the lowest from February to May. The highest values were found in the rhizomes $(16.4 \%$ relative to dry wt, Fig. 4c), as well as the highest differences between seasonal minimum and maximum rates $(12 \%$ relative to dry wt, Fig. 4c). The lowest values were found in the oldest leaves $(1.1 \%$ relative to dry wt in February), which also presented the minimum seasonal differences (3\% relative to dry wt, see Fig. $4 \mathrm{a})$.

Within-shoot age variability was high (Fig. 4a), with the younger age classes ( 0 to 25 and 25 to $50 \mathrm{~d}$ ) pre-

Table 3. Analysis of variance (ANOVA) to test the effect of seasonality (i.e. sampling events) on respiration $\left(\mathrm{mg} \mathrm{O}_{2} \mathrm{DW}^{-1}\right.$ $\mathrm{h}^{-1}$ ) of belowground organs and total non-structural carbon content (\% TNC) in the different plant organs and leaf age classes (A1 to A4, see text). Treatment effects were considered statistically significant if ${ }^{*} p<0.05,{ }^{* *} p<0.01$ and ${ }^{* * *} \mathrm{p}<0.001$. ns: non-significant

\begin{tabular}{|lcl|}
\hline Variable & $F$ & Significance \\
\hline Sheath respiration & 3.61 & $*$ \\
Root respiration & 12.72 & ${ }^{* *}$ \\
Rhizome respiration & 3.31 & $\mathrm{~ns}$ \\
$\%$ TNC in A1 & 0.297 & $\mathrm{~ns}$ \\
$\%$ TNC in A2 & 2.037 & $\mathrm{~ns}$ \\
$\%$ TNC in A3 & 3.416 & ${ }^{*}$ \\
$\%$ TNC in A4 & 11.91 & ${ }^{* * *}$ \\
$\%$ TNC in rhizome & 20.28 & ${ }^{* * *}$ \\
$\%$ TNC in root & 3.965 & $*$ \\
$\%$ TNC in sheaths & 0.996 & $\mathrm{~ns}$ \\
& & \\
\hline
\end{tabular}



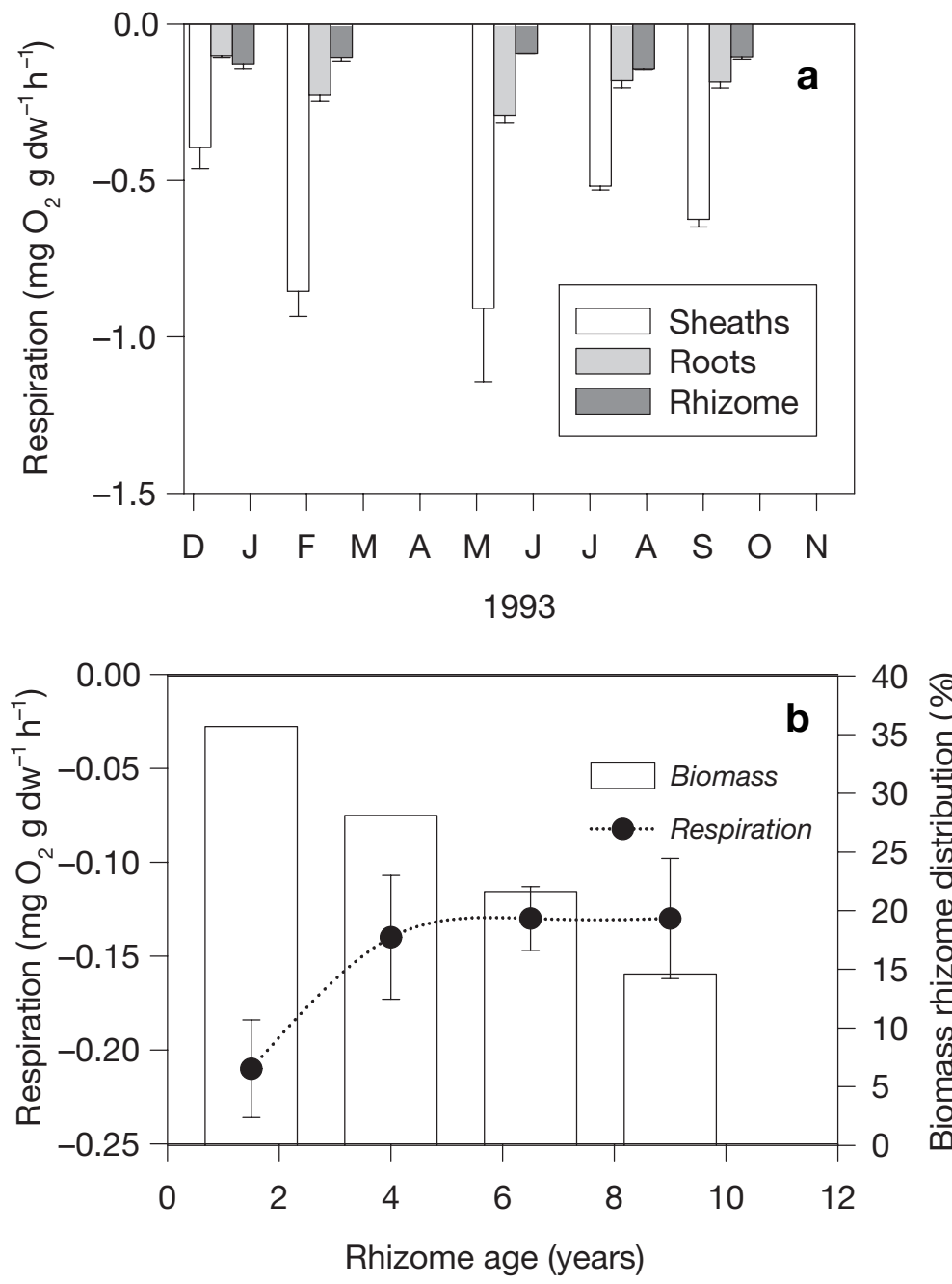

Fig. 3. (a) Seasonal variation in the respiration of the rhizome, roots and sheaths (attached to the leaf) and (b) within rhizome biomass distribution and respiration following tissue age (yr). Error bars represent the standard error $(n=3)$

senting the highest values of TNC, but without any seasonal effect (Table 3). Older age classes had the lowest values, but with a clear seasonal trend as described above (Table 3, Fig. 4a).

\section{Whole-plant $\mathbf{C}$ balance}

C gain or loss of photosynthetic tissue was very low from fall to spring (Fig. 5a), due both to the low surface irradiance (Fig. 1a) and to the reduced daylength. In summer, the balance was markedly higher, especially in July and August, as a result of the amelioration of the light conditions and the high $P_{\max }$ values during this period (Table 1). Epiphyte decreased the annual net photosynthetic C gain by $4 \%$ (Fig. 5 a).

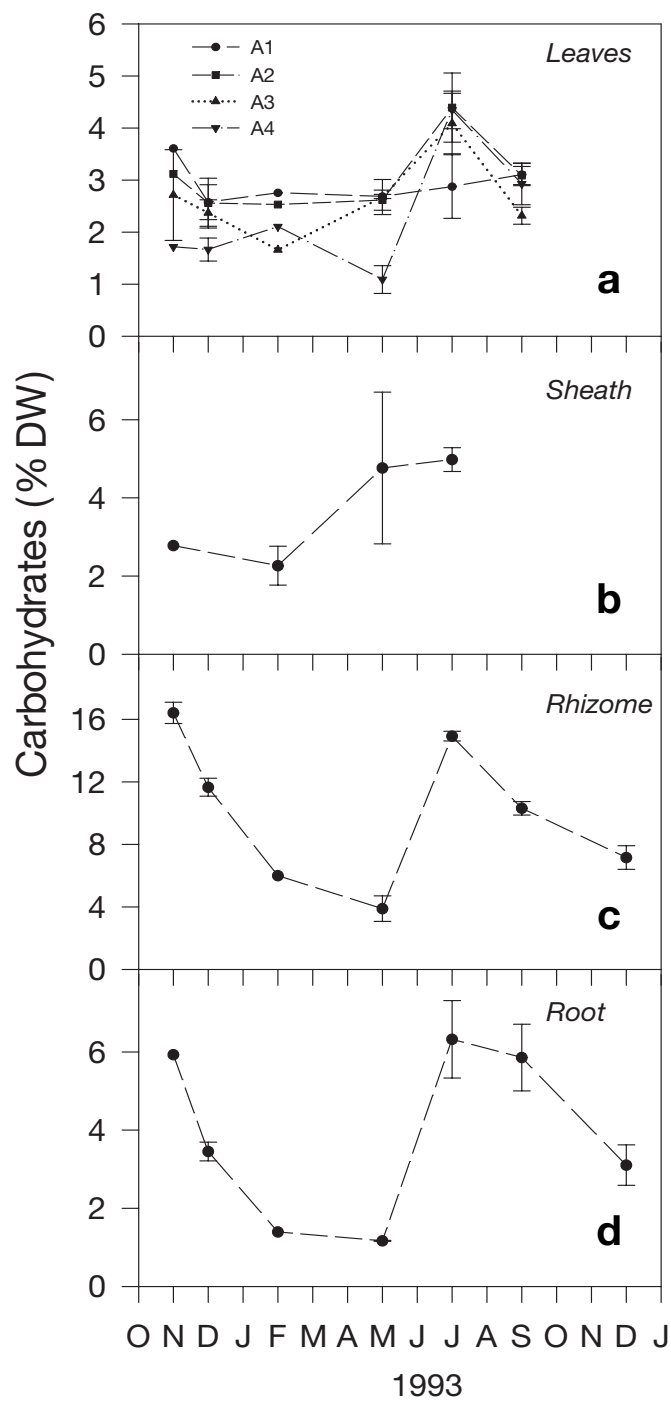

Fig. 4. Seasonal TNC (total nonstructural carbohydrate) variation from (a) leaves (following the age of the leaf tissues), (b) sheath, (c) rhizome and (d) root. The photosynthetic parts were sorted into segments corresponding to the following age classes (in days): A1, leaf 0 to $25 \mathrm{~d}$; A2, leaf 25 to $50 \mathrm{~d} ; \mathrm{A} 3$, leaf 50 to $100 \mathrm{~d}$; A4, leaf 100 to $150 \mathrm{~d}$. Error bars represent the standard error $(n=$ between 3 and 6)
The integrated C demand of the total non-photosynthetic tissue was highest in May (Fig. 5b), which is mostly a result of the higher respiration of the roots (Fig. 5b). Carbon demand for growth (Fig. 5c) paralleled shoot growth (Fig. 2), as a result of the low variability in carbon concentration in the different tissues and the assumed lack of seasonality in growth rates of the non-photosynthetic organs (Table. 2). The period May to June had the highest values followed by a sharp decrease in fall (Fig. 5c). 
Whole-plant $\mathrm{C}$ balance showed alternate periods of negative and positive values (Fig. 5d). Negative carbon balance occurred from fall to spring, while positive carbon balance occurred only during the summer months (Fig. 5d). Annual whole-plant carbon balance was clearly dependent on the parameters used for the C balance calculations (Table 4). However, in 1993 the annual balance was negative for all cases, while in 1994 the annual balance switched from negative to positive depending on the molar quotient (1.2 or 1.0 respectively; see Table 4).

\section{DISCUSSION}

\section{Predictability of underwater irradiance in Mediterranean waters}

The accuracy in the measurement (or estimation) of photosynthetic active radiation reaching the plant canopy seems a crucial aspect in the reliability of any carbon balance (Zimmerman et al. 1994). Our calculations show that most of the variability of the underwater irradiance can be attributed to variability of the surface solar irradiance. The variability in water transparency was small, and therefore has a minor impact on underwater irradiance variability. This is due to (1) the relative shallowness of our study site $(5 \mathrm{~m})$, and (2) the specificity of the Mediterranean waters, including the lack of tidal movements generating daily cycles of turbidity and the scarcity of nutrients (and associated high transparency; Poole \& Atkins 1929, Weinberg 1976, Ivanoff 1977). This is in contrast with the large variability found by other authors in quite different marine environments, such as areas under the influence of upwelling waters or estuaries (Dunton 1994, Zimmerman et al. 1994), which precludes a correct assessment of underwater light except when using continuous recording. This is not the case for the much more predictable Mediterranean area.

\section{Importance of belowground carbon losses in the C-budget of Posidonia oceanica}

Respiratory rates of Posidonia oceanica belowground organs (rhizome, root and sheaths) have been observed to be very low and dependent either on tissue age (e.g. rhizomes) or on seasonal constraints (e.g. roots and leaf sheaths). Such seasonality does not seem to rely on the yearly temperature cycle, but mainly on metabolic constraints, such as the onset of the winter growth, implicating reserves remobilization. Kraemer \& Alberte (1993) also found low respiratory rates for the belowground (roots and rhizome) organs in the eel-

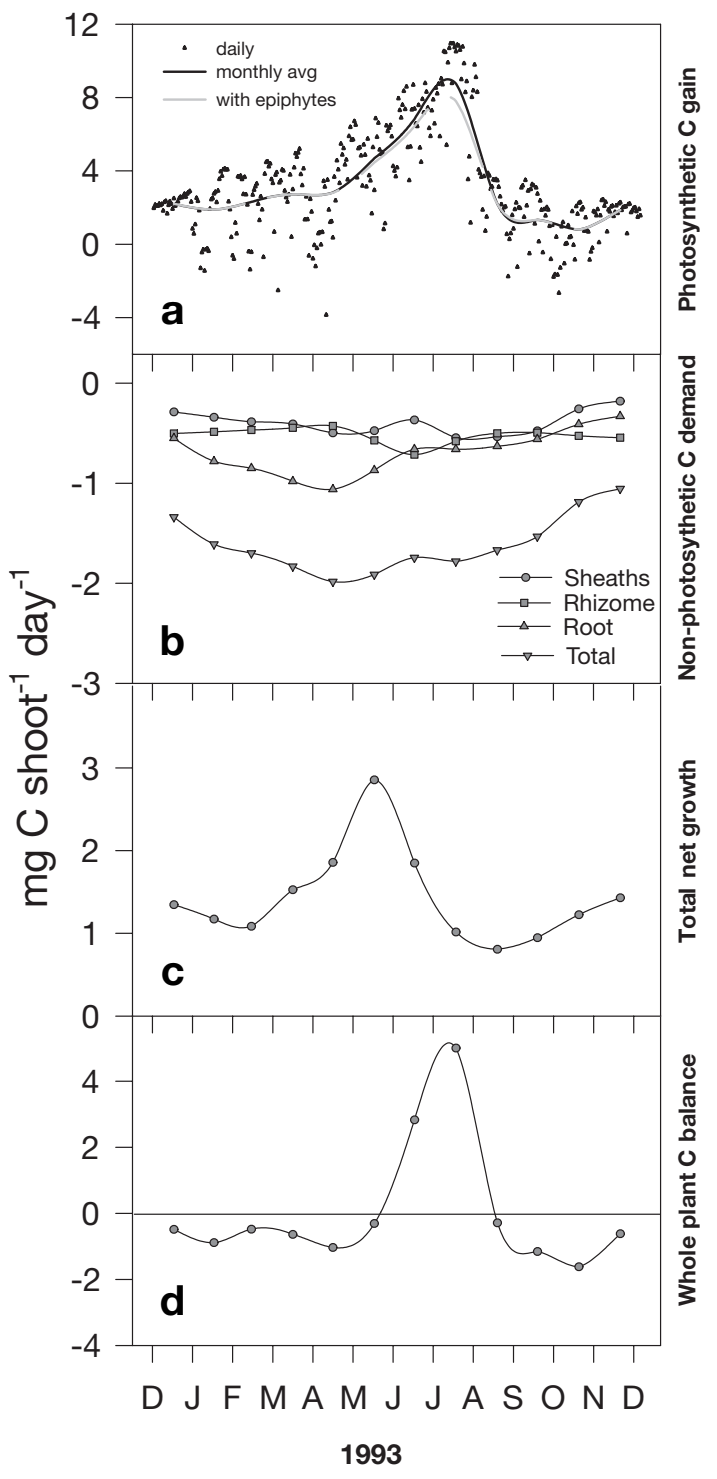

Fig. 5. Monthly changes in (a) metabolic $\mathrm{C}$ gain of the photosynthetic tissue (daily and monthly averages and including the epiphyte cover), (b) non-photosynthetic $\mathrm{C}$ demand, (c) total $\mathrm{C}$ for growth and (d) whole-plant $\mathrm{C}$ balance $\left(\mathrm{mg} \mathrm{C}\right.$ shoot $\left.^{-1} \mathrm{~d}^{-1}\right)$

grass Zostera marina with a clear decrease following tissue aging, and concluded that total plant respiration was strongly controlled by shoot carbon metabolism. However, this does not seem the case in $P$. oceanica since even the low respiratory rates reported here represent an important demand due to the very high biomass of these organs, which account for 60 to $86 \%$ (summer-winter) of the total biomass. Other examples in the literature of high belowground biomass are found in the seagrass Thalassia testudinum, where belowground tissue constitutes between 55 and $90 \%$ of the total biomass and represents more than $50 \%$ of 
the total plant respiration (Fourqurean \& Zieman 1991). In fact, recent studies on $T$. testudinum have considered the high sensitivity of carbon balance models to the relative shoot:rhizome + root ratio, and thus, how critical the correct estimation of the oxygen demand of the belowground organs can be (Dunton \& Tomasko 1994, Hemminga 1998, Herzka \& Dunton 1998). In addition to respiratory losses, other carbon losses through roots may occur, such as a soluble carbon excretion in moments of maximum carbohydrate synthesis (Welsh et al. 1997) or release of fermentation products, which would occur under hypoxic conditions (Smith et al. 1984). The quantitative importance of such potential processes is unknown in P. oceanica.

\section{Carbohydrate pool}

Seasonal changes in TNC content in Posidonia oceanica are consistent across plant organs and leaf age classes. The clear seasonal trend, which seems to be constant across a wide geographical area (Pirc 1989, Genot et al. 1994), and the absence of noise in the series indicate the dependence of the carbon pool on seasonal factors (large-scale factors, i.e. solar cycle). This is in contrast with some findings in terrestrial plants, especially crop plants, which clearly show daily fluctuations (Rufty et al. 1983, Sicher 1984, Kalt-Torres \& Huber 1987). The absence of nighttime sucrose depletion in leaves of other seagrass species (Zostera marina; Zimmerman et al. 1995) suggests that seagrasses probably have a pool of carbohydrates high enough to buffer the daily fluctuations in light availability without great changes, since most of the variability in carbohydrate content is reflected at a seasonal scale. However, interannual variability should not be discarded, since our data showed that the carbohydrate pool was higher in winter 1992 than in winter 1993 (Fig. 6).

\section{Growth prediction}

It is also worth noting the impossibility of predicting seasonal growth from the metabolic balance (plant C balance excluding growth) as demonstrated by the lack of correlation between these 2 variables $\left(R^{2}=0.06\right.$, $\mathrm{p}=0.40)_{\text {; }}$ in other words, leaf elongation at any moment within a year cycle does not depend on a positive metabolic balance (when carbon gains exceed carbon demands). Posidonia oceanica growth starts in winter and reaches a maximum in June, when irradiance is not yet at a maximum and the $\mathrm{C}$ balance of the plant is not yet positive. This growth can only be sustained by the carbohydrate reserves, which meet the

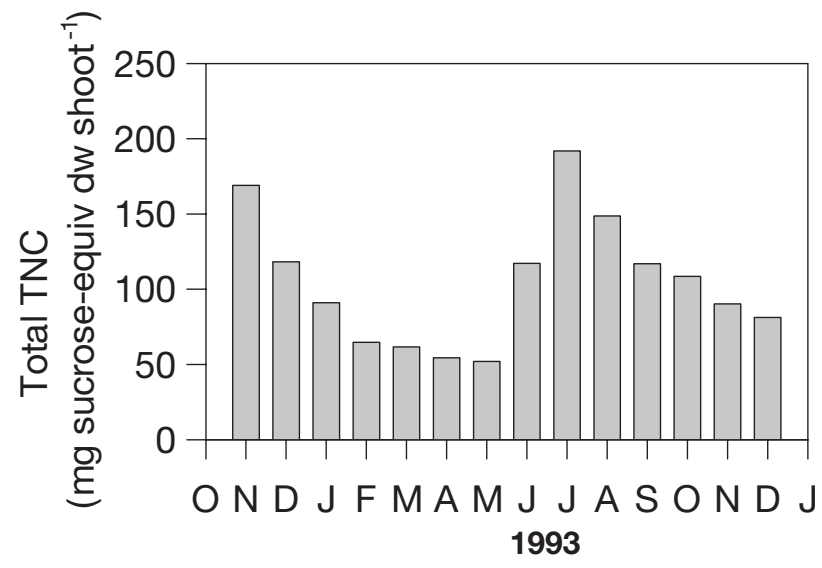

Fig 6. Monthly changes in whole-plant TNC (total nonstructural carbohydrate) considering the relative biomass of each tissue (leaves, sheaths, rhizome and roots)

respiratory demands and support the re-growth after massive autumnal leaf losses. With this early growth the leaf canopy will be well developed in May-June, before the occurence of maximum irradiance conditions. Thus photosynthetic carbon fixation is maximized in the reduced time interval (June to September) in which light conditions are optimal, and this allows the plant to store enough reserves to overwinter and re-grow. During this period it is also possible, as the increased metabolism in the rhizosphere of Zostera noltii infers (Welsh et al. 1997), that plants are prone to excrete carbon compounds into the rhizosphere. Supply and demand asynchrony seems to be the rule rather than the exception for terrestrial plants (Chapin 1990), and growth demand may be largely supported by stored reserves. In P. oceanica, there is also an asynchrony between nutrient and light availability. During July to August, when a positive carbon balance can be achieved, nutrient availability both in the water column (Romero 1985) and in the pore water (Alcoverro et al. 1995) are at a minimum, and plant growth is nutrient-limited (Alcoverro et al. 1997b). In contrast, during winter, when nutrient concentrations are high, light conditions do not permit net carbon gains. Hence, the described pattern of carbohydrate storage would not only facilitate reaching July and August with a large photosynthetic biomass, but would also enable an important part of the annual leaf growth to take place during nutrient-sufficient conditions. This could be analogous to the annual growth cycle of some species of macroalgae, such as those described by Chapman \& Craige (1978). In the case of $P$. oceanica, the growth cycle may be controlled by an internal rhythm (Ott 1979), as has been observed in other seagrass species (Dunton 1994), which is probably synchronized by external factors (i.e. light; Lüning 1991, Lüning \& Kadel 1993). 


\section{Coupling between whole-plant $\mathrm{C}$ balance and carbohydrate pool}

Posidonia oceanica carbon balance seasonality is the result of the interplay among several seasonal factors such as light, water turbidity, photosynthetic parameters, respiratory rates, shoot growth, within-shoot age distribution, non-photosynthetic:photosynthetic biomass ratio and epiphyte cover. Herzka \& Dunton (1998) conclude that even healthy seagrass populations, as in Thalassia testudinum, may undergo periods of negative carbon balance depending on a variety of factors such as season, previous history or physiological tolerance to anoxia. Likewise, Chabot \& Hicks (1982) have suggested that the amount of carbon lost during an unfavorable season depends on its duration and severity. In $P$. oceanica, the alternate seasonal periods of carbon removal and storage are consistent with the periods in which the $\mathrm{C}$ balance is negative (depletion of the carbohydrate reserves) and positive (refill of the carbohydrate reserves, Fig. 7). The average rates of reserve mobilization (which can represent up to $0.7 \mathrm{mg} \mathrm{C}$ shoot $^{-1}$ $\mathrm{d}^{-1}$ ) and the accumulation (up to $1 \mathrm{mg} \mathrm{C}$ shoot $^{-1} \mathrm{~d}^{-1}$ ) are consistent with the estimates of $\mathrm{C}$ deficit or excess during the negative/positive periods of our $\mathrm{C}$ budget (Fig. 7).

\section{Validity of annual $\mathrm{C}$ balance budgets}

A solid criticism that can be adduced in the annual calculation of the metabolic $\mathrm{C}$ balance is that some parameters that definitively influence the results (e.g. reduction of belowground respiration during the night hours; oxygen conversion to carbon units) have been used indistinctly in the literature dealing with seagrass C balances (Zimmerman et al. 1996, Herzka \& Dunton 1998). For Zostera marina, the belowground organs consumption during the dark period has been observed to be $65 \%$ of the rate in the light period (Smith et al. 1984). Annual average redox potential in the Medes Island station (74 mV, Alcoverro et al. 1995) is low enough to support this assumption. During the anaerobic period, fermentation processes have been reported to be of more importance than respiration in root metabolism. These fermentation products can be excreted and may represent an additional C-loss.

The $\mathrm{O}_{2}$ to $\mathrm{C}$ conversion has been observed to be another point of controversy in part because no data are available about this conversion in seagrasses. In the case of terrestrial plants that use starch and sugars as respiratory substrates, as observed in Posidonia oceanica, the equivalence $1 \mathrm{~mol}$ of $\mathrm{O}_{2}: 1 \mathrm{~mol} \mathrm{CO}_{2}$ seems widely accepted. However, more physiological experiments should be done to further prove this hypothesis in seagrasses.

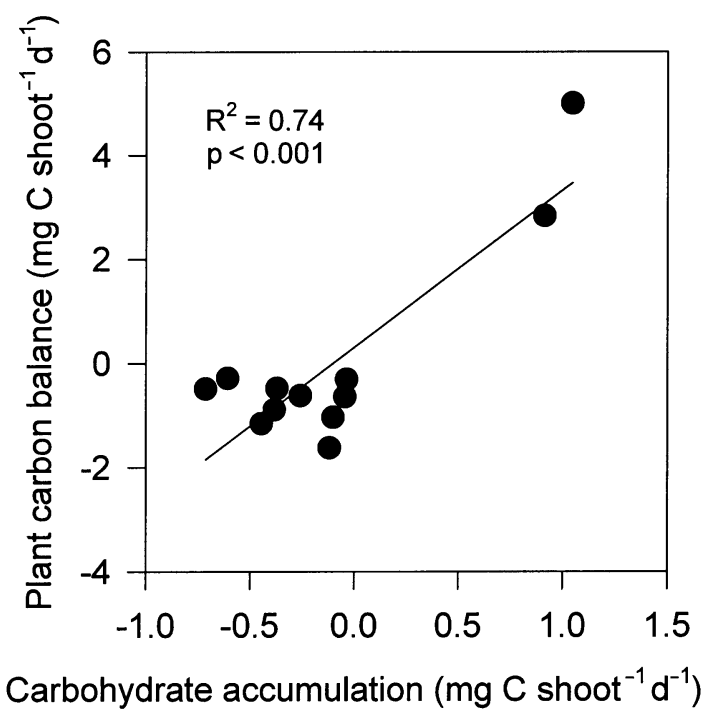

Fig 7. Monthly correlation between carbohydrate accumulation (data transformed from sucrose to $\mathrm{C}$ units using the molecular weight) and whole-plant $\mathrm{C}$ balance

Nevertheless, due to the uncertainty as to the use of those parameters not yet been evaluated for Posidonia oceanica and assuming all these sources of variation, the resultant annual whole-plant C balance for 1993 was in all cases negative (Table 4), while the balance for the following year (1994) was positive or negative depending on the photosynthetic ratio used for the calculation. These paradoxical results show the difficulty in obtaining accurate annual estimates even when all the variables are measured. However, the most important conclusion for this annual carbon balance calculation is the negative value in all approximations which can be explained by the low irradiance that occurred during 1993 compared to 1994 (annual daily average irradiance was 2334 and $2455 \mathrm{~W} \mathrm{~m}^{-2} \mathrm{~d}^{-1}$ respectively). These results are also in accordance with the interannual rhizome carbohydrate drop stressed above and with the shoot density decrease (593 shoots $\mathrm{m}^{-2}$ in 1993 compared to 481 shoots $\mathrm{m}^{-2}$ in 1994, Romero et al. 1996) observed. The support of stored reserves from senescing shoots and rhizomes might enable $P$. oceanica to remain alive under conditions of insufficient light but if the light limitation were to persist, it could have severe effects on the seagrass recovery. The interannual decrease between the 2 consecutive yr of the total reserves $(31 \%)$ is in accordance with the shoot density reduction $(19 \%)$. This interannual carbohydrate reserves variability may provide an easy and useful index for assessing an eventual $P$. oceanica density decline. 
In summary from the data presented here, 3 facts of major significance emerge: first, the importance of respiratory losses associated with the belowground organs which make Posidonia oceanica very sensitive to reductions in light availability (pulsed or continuous); second, the clear asynchrony between carbon fixation (photosynthesis) and carbon use (respiration or growth), which is balanced by the storage of carbohydrate reserves; and third, the interannual variability in the carbon balance, which is reflected in interannual changes in both carbohydrate reserves and shoot density values. Since $P$. oceanica is regressing in the Mediterranean, our carbon budget may notably contribute to future carbon models which are essential tools for defining the minimum light requirements of this plant. However, more insight into the functioning of some of the parameters that definitively influence this carbon budget is needed to fully understand the vulnerability of seagrasses to light.

Acknowledgements. This work was supported by the grant MAR98-0356. We thank Marta Pérez and the former Erasmus students Josep López, Núria López and Esther Benavent for their help, both in the field and in the laboratory. Fundació Mas Badia (Estació Experimental Agrícola) kindly provided irradiance data. Josep Pascual kindly provided Secchi disk data from l'Estartit (Girona, Spain). Four anonymous reviewers provided very useful comments and suggestions.

\section{LITERATURE CITED}

Abdel-Razik M (1989) A model of the productivity of olive trees under optimal water and nutrient supply in desert conditions. Ecol Model 45:179-204

Alcoverro T, Duarte CM, Romero J (1995) Annual growth dynamics of Posidonia oceanica: contribution of largescale versus local factors to seasonality. Mar Ecol Prog Ser 120:203-210

Alcoverro T, Duarte CM, Romero J (1997a) Posidonia oceanica epiphytes in the NW Mediterranean: the influence of herbivores. Aquat Bot 56:93-104

Alcoverro T, Romero J, Duarte CM, López NI (1997b) Spatial and temporal variations in nutrient limitation of seagrass Posidonia oceanica growth in NW Mediterranean. Mar Ecol Prog Ser 146:155-161

Alcoverro T, Manzanera M, Romero J (1998) Seasonal and age-dependent variability of Posidonia oceanica (L.) Delile photosynthesis and respiration. J Exp Mar Biol Ecol 230: $1-13$
Alcoverro T, Zimmerman RC, Kohrs DG, Alberte RS (1999) Resource allocation and sucrose mobilization in light-limited eelgrass Zostera marina. Mar Ecol Prog Ser 187: 121-131

Alcoverro T, Manzanera M, Romero J (2000) Nutrient mass balance of the seagrass Posidonia oceanica: the importance of nutrient retranslocation. Mar Ecol Prog Ser 194: 13-21

Buwalda JG (1991) A mathematical model of carbon acquisition and utilisation by kiwifruit vines. Ecol Model 57: $43-64$

Cebrián J, Duarte CM, Marbà N, Enríquez S (1997) Magnitude and fate of the production of four coocurring Western Mediterranean seagrass species. Mar Ecol Prog Ser 155: $29-44$

Chabot BF, Hicks DJ (1982) The ecology of leaf spans. Annu Rev Ecol Syst 13:229-259

Chapin FS III (1990) The ecology and economics of storage in plants. Annu Rev Ecol Syst 21:423-447

Chapman ARO, Craigie JS (1978) Seasonal growth in Laminaria longicruris: relations with reserve carbohydrate storage and production. Mar Biol 46:209-213

Duarte CM, Cebrián J (1996) The fate of marine autotrophic production. Limnol Oceanogr 507:1758-1766

Dunton KH (1990) Growth and production in Laminaria solidungula: relation to continuous underwater light levels in the Alaskan High Artic. Mar Biol 106:297-304

Dunton KH (1994) Seasonal growth and biomass of the subtropical seagrass Halodule wrightii in relation to continuous measurements of underwater irradiance. Mar Biol $120: 479-489$

Dunton KH, Tomasko DA (1994) In situ photosynthesis in the seagrass Halodule wrightii in a hypersaline tropical lagoon. Mar Ecol Prog Ser 107:281-293

Edwards G, Walker D (1983) C3 C4 mechanisms and cellular and environmental regulation of photosynthesis. Blackwell Scientific, Oxford

Fourqurean JW, Zieman JC (1991) Photosynthesis respiration and whole plant carbon budget of the seagrass Thalassia 
testudinum. Mar Ecol Prog Ser 69:161-170

Genot I, Caye G, Meinesz A, Orlandini M (1994) Role of chlorophyll and carbohydrate contents in survival of Posidonia oceanica cuttings transplanted to different depths. Mar Biol 119:23-29

Gutiérrez AP, Williams DW, Kido H (1985) A model of grape growth and development: the mathematical structure and biological considerations. Crop Sci 25:721-728

Heim C, Landsberg JJ, Watson RL, Brain P (1979) Eco-physiology of apple trees: dry matter partitioning by young Golden Delicious apple trees in France and England. J Appl Ecol 16:179-194

Hemminga MA (1998) The root/rhizome system of seagrasses: an asset and a burden. J Sea Res 39:183-196

Herzka SZ, Dunton KH (1998) Light and carbon balance in the seagrass Thalassia testudinum: evaluation of current production models. Mar Biol 132:711-721

Hootsman MJM, Vermaat JE (1985) The effect of periphytongrazing by the three epifaunal species on the growth of Zostera marina L. under experimental conditions. Aquat Bot 22:83-88

Ivanoff A (1977) Oceanic absorption of solar energy. In: Kraus EB (ed) Modelling and prediction of the upper layers of the ocean. Pergamon Press, Oxford, p 47-71

Janecek A, Benderoth G, Lüdeke MKB, Kinderman J, Kohlmaier GH (1989) Model of the seasonal and perennial carbon dynamics in deciduous-type forests controlled by climatic variables. Ecol Model 49:101-124

Kalt-Torres W, Huber SC (1987) Diurnal changes in leaf maize photosynthesis. III. Leaf elongation in relation to carbohydrates and activities of sucrose metabolizing enzymes in elongating leaf tissue. Plant Physiol 83:294-298

Kirk JTO (1983) Light and photosynthesis in aquatic ecosystems. Cambridge University Press, Cambridge

Kraemer GP, Alberte RS (1993) Age-related patterns of metabolism and biomass in subterranean tissues of Zostera marina (eelgrass). Mar Ecol Prog Ser 95:193-203

Lee KS, Dunton KH (1997) Effects of in situ light reduction on the maintenance, growth and partitioning of carbon resources in Thalassia testudinum. J Exp Mar Biol Ecol 210:53-73

Lüning K (1991) Circannual growth rhytms in a brown alga Pterygophopra californica. Bot Acta 104:157-162

Lüning K, Kadel P (1993) Daylength range for circannuual rhythmicity in Pterygophora californica (Alariaceae Phaephyta) and synchronization of seasonal growth by daylength cycles in several other brown algae. Phycologia 32 : 379-387

Makela A, Hari P (1986) Stand growth models based on carbon uptake and allocation in individual trees. Ecol Model 33:205-229

Manzanera M, Alcoverro T, Romero J (1998) The role of the remnant leaf sheaths (scales) attached to the Posidonia oceanica (L.) Delile rhizomes. J Exp Mar Biol Ecol 223: 257-270

Marbà N, Duarte CM (1996) Growth and population dynamics of Posidonia oceanica on the Spanish Mediterranean coast: elucidating seagrass decline. Mar Ecol Prog Ser 137: 203-213

Mateo MA (1995) Papel ecológico de las necromasa en praderas de fanerógamas marinas. Doctoral thesis, Barcelona

Mateo H, Romero J (1997) Necromass dynamics in the seagrass Posidonia oceanica: elements for an ecosystem carbon and nutrient budget. Mar Ecol Prog Ser 151:43-53

Ott JA (1979) Persistence of a seasonal growth rhythm in Posidonia oceanica (L.) Delile under constant conditions of temperature and ilumination. Mar Bio Lett 1:99-104
Ott JA (1980) Growth and production of Posidonia oceanica (L.) Delile. PSZN I: Mar Ecol 1:47-64

Pérez M, Romero J (1992) Photosynthetic response to light and temperature of the seagrass Cymodocea nodosa and the prediction of its seasonality Aquat Bot 43:51-62

Pergent G, Boudouresque CF, Crouzet A (1983) Variations cycliques dans les écailles des rhizomes orthotropes de Posidonia oceanica. Trav Sci Parc Natl Port-Cros Fr 9:107-148

Pergent G, Boudouresque CF, Crouzet A, Meinesz A (1989) Cyclic changes along Posidonia oceanica rhizomes (lepidochronology): present state and perspectives. PSZN I: Mar Ecol 10:221-230

Pirc H (1983) Belowground biomass of Posidonia oceanica (L.) Delile and its importance to the growth dynamics. In: Proceedings International Symposium on Aquatic Macrophytes, Nijmegen, p 77-81

Pirc H (1989) Seasonal changes in soluble carbohydrates starch and energy content in Mediterranean seagrasses. PSZN I: Mar Ecol 10:97-105

Poole HH, Atkins RG (1929) Photo-electric measurement of submarine illumination throughout the year. J Mar Biol Assoc UK (NS) 16:297-324

Romero J (1985) Estudio ecológico de las fanerógamas marinas de la costa catalana: producción primaria de Posidonia oceanica L Delile en las Islas Medas. Doctoral thesis, Barcelona

Romero J (1989) Primary production of Posidonia oceanica beds in the Medes Islands (Girona NE Spain). In: Boudouresque CF, Meinesz A, Fresi E, Gravez V (eds) International Workshop on Posidonia Beds, Vol 2. GIS Posidonie, Marseille, p 85-91

Romero J, Pérez M, Invers I, Manzanera M, de Pedro X (1996) Estado biológico de la pradera de Posidonia oceanica de las islas Medes. Departament d'Agricultura, Ramaderia i Pesca, Barcelona

Rufty TW, Kerr PS, Huber SC (1983) Characterization of diurnal changes in activities of enzymes involved in sucrose biosynthesis. Plant Physiol 73:428-433

Sánchez-Lizaso JL, Guillén-Nieto JE, Ramos-Esplá AA (1990) The regression of Posidonia oceanica meadows in El Campello (Spain). Rapp Comm Int Mer Medit 32:7

Sand-Jensen K (1977) Effect of epiphytes on eelgrass photosynthesis. Aquat Bot 3:55-63

Seem RC, Elfving DC, Oren TR, Eisensmith SP (1986) A carbon balance model for apple tree growth and function. Acta Hortic 184:129-137

Sicher RC, Kremer DF (1984) Changes in sucrose-phosphate synthase activity in barley primary leaves during light/dark transitions. Plant Physiol 76:910-912

Silberstein K, Chiffings AW, McComb AJ (1986) The loss of seagrass in Cockburn sound western Australia III. The effect of epiphytes on productivity of Posidonia australis Hook F. Aquat Bot 24:355-371

Sokal RR, Rohlf FJ (1981) Biometry. Freeman \& Co, New York

Valiela I (1995) Marine ecological processes, 2nd edn. Springer-Verlag, New York

Weinberg S (1976) Submarine daylight and ecology. Mar Biol 37:292-304

Weinberg S, Cortel-Breeman A (1978) The estimation of the yearly cycle of submarine irradiance for ecological purposes. A methodological example based on data from Banyuls-sur-mer (France). Bijdr Duk 42:35-44

Welsh DT, Bourguès S, de Wit R, Auby I (1997) Effect of plant photosynthesis, carbon sources and ammonium availability on nitrogen fixation rates in the rhizosphere of Zostera noltii. Aquat Microb Ecol 12:285-290

Zavodnik N, Jaklin A (1990) Long-term changes in the North- 
ern Adriatic marine phanerogam beds. Rapp Comm Int Mer Médit 32:15

Zimmerman R, Cabello-Pasini A, Alberte RS (1994) Modelling daily production of aquatic macrophytes from irradiance measurements: a comparative analysis. Mar Ecol Prog Ser 114:185-196

Editorial responsibility: Otto Kinne (Editor),

Oldendorf/Luhe, Germany
Zimmerman RC, Kohrs DG, Alberte RS (1995) Carbon partitioning in eelgrass. Plant Physiol 108:1665-1671

Zimmerman RC, Kohrs DG, Alberte RS (1996) Top-down impact through a bottom-up mechanism: the effect of limpet grazing on growth productivity and carbon allocation of Zostera marina L. (eelgrass). Oecologia 107:560-567

Submitted: December 8, 2000; Accepted: June 22, 2000 Proofs received from author(s): January 22, 2001 